\title{
Links among Quality, Satisfaction, Value, and Repurchase Intention in Gated Communities: Case from Kurdistan Region of Iraq
}

\author{
Zrian Ibrahim $^{1} \&$ Khayal Mahsum Faraj ${ }^{2}$
}

\begin{abstract}
${ }^{1 \& 2}$ Department of Business and Management, Faculty of Administrative Sciences and Economics, Tishk International University, Sulaimani, Iraq

Correspondence: Khayal Mahsum Faraj, Tishk International University, Sulaimani, Iraq.

Email: khayal.jaf@tiu.edu.iq
\end{abstract}

Doi: 10.23918/ejmss.v1i1p60

\begin{abstract}
The aim of this research was to elaborate the impact of product quality, service quality, customer satisfaction, and perceived value on the repurchase intentions of the residents in a gated community. We have collected data from the residents in various gated communities. Collected data was analyzed via structural equations modeling. The results reveal that product quality is a stronger influencer on the customer satisfaction than the service quality. Secondly, it was observed that product quality had significant impact on the perceived value while service quality was mediated on the perceived value via customer satisfaction. Lastly, it was observed that perceived value was very important determinant of repurchasing intentions of residents at a gated community and it was affected by customer satisfaction strongly. Service and product quality explained $56 \%$ of the variance on the customer satisfaction while they have explained $76 \%$ of the variance on perceived value and $65 \%$ of the variance on the repurchase intention.
\end{abstract}

Keywords: Service Quality, Product Quality, Gated Community, Repurchase Intention, Perceived Value, Customer Satisfaction

\section{Introduction}

Gated communities are residential neighborhood that are segregated or in other words fenced or gated. These communities have a certain level of security that obviously is higher than a typical community and resident in these communities have a different lifestyle and they are of the same socio-economic class (Demir \& Mukhlis, 2019). Gated communities 
are housing development which have limited access and are separated by a fence or wall from the rest of the city (Kovacs \& Hegedus, 2014; Blakely \& Snyder, 1997). Moreover, Gated Communities can be defined as a guarded place which is surrounded by wall or any kind of borders to be secured and controlled by security guards (Lai, 2016).

Gated communities are demanded by people for various reasons such as protection, recreational facilities, ethnicity and services (Smigiel, 2014). According to Atkinson et al. (2005) the gated communities are the response to the fear of crime that are looking for status, privacy, and the potential investment. They include private property, individual houses and collectively used common private property, for example clubhouse and sports facilities. Moreover, security is an important driver in these cities; controlled walls, fences, gates, barriers, alarms, guards and CCTV cameras and the high quality of infrastructure. These communities have been designed with the intention of providing security to their residents and prevent penetration by non-residents (Sonia, 2005). Similarly, Greenberg and Rohe (1984) note these communities with boundaries or wall and less permeable to nonresident had a lower crime rate than the opened communities (Gregory, 2013; Hope, 2000; Low, 2003).

Many factors affect customer satisfaction including service quality, billing clarity, good value, friendly and knowledgeable employee (Hokanson, 2019; Budur, 2018a; Jaf, Muhammed \& Omer, 2019). Satisfaction is a feeling of acceptance, happiness, relief, excitement and delight (Budur et al., 2018; Demir, 2019; Khan \& Yildiz, 2020). Kotler (2000) defined satisfaction as a person's feeling of pleasure or disappointment resulting from an evaluation process comparing the product perceived performance in relation to his/her expectation. Perceived service quality has a positive effect and significant impact on the level of customer satisfaction (Natalia \& Subroto, 1998). The higher level of service quality affects value perception, satisfaction and also influences the repurchase intention of service or product (Cronin et al., 2000; Kandampully \& Juwaheer, 2009). According to Parasuraman et al. (1988) there is a positive relationship between perceived service quality and the behavioral intentions such as word of mouth, intention to come back and eagerness to recommend to other. Likewise, satisfaction and perceived product quality has a direct positive effect on repurchase intentions which is correlated with the managers affection on the employees (Tsiotsou, 2006; Budur, 2018b; Budur et al., 2019; Ali et al., 2020) 
Product quality is generally measured by the people who use the product and evaluate their pleasure respectively (Bowen \& Ford, 2002). Product quality is an important element that helps to gain the customer satisfaction and is a competitive advantage for provider (Zhang, Vonderembse \& Lim, 2003; Ayldinli \& Demir, 2015; Torlak, Demir \& Budur, 2019). Good product means satisfied customers and leading to build the trust between the customer and the provider (Hilal \& Top, 2019). High-quality products (services included) allow companies to command premium prices or sell more of their products at a given price, which leads to a higher profit (Porter, 1985).

Service quality is the understanding of customers and meet their needs accordingly by managing service and delivery to satisfy customers (Sidin et al., 2001). Service quality is a measure of how organization serves their customers and how customer evaluate the service received (Jaf et al., 2019). It is important for companies to understand their customer expectation to have better performance and make the business last longer (Hilal $\&$ Top, 2019). Therefore, it is a need for organization to evaluate their service periodically and plan for improvement (Jaf et al., 2019; Demir et al., 2019).

Gated communities in Kurdistan region of Iraq have been increasing enormously in recent years (Demir, et al., 2014; Ozmen et al., 2013). The electricity supply is one of the main problems of the region. According to the predictions of Demir (2014) in the gated communities' electricity is provided seven-day 24 hours. Further, Kurdistan region is suffering from different political problems (Serin, 2018; Yildiz \& Budur, 2019; Mohammed et al., 2020) which is affecting people's lifestyle indirectly and the region recently has suffered from ISIS war and this situation makes people try to live behind the gate for being secured from a sudden attack (Budur \& Demir, 2019a). That's why, in the recent years the number of gated communities are increased and will continue to increase whereas the gated communities provide a service that make their life easier and keep the privacy which families prefer.

\section{Literature Review}

\subsection{Service Quality}

Service quality can be defined as the difference between customer expectation and the perception (Groonos, 1984; Parasurman, 1991; Shahin, 2010) while the most common definition has been contributed by Parasuraman et al. (1985, 1998, and 1991), where the 


\section{EJMSS}

Eurasian Journal of Management \& Social Sciences

Service quality is a framework which can help one to understand the reasons of customer satisfaction (Aydinli \& Demir, 2015). Further, perceived service quality can be defined as the customer's judgment about superiority or excellence of a product (Zeithmal,1988; Demir, 2019b). Moreover, service quality proposed to understand how well an actual service delivery matches with customer expectations and experience with product or serviced received (Torlak, Demir, \& Budur, 2019).

In this respect, the customers of service organizations are considered as one of the primary determinants in business performance (Parikh, 2006). So far, scholars noted service quality brings certain benefit to the organization such as low turnover, customer satisfaction and retention, lower operating cost, positive word of mouth, increasing in profit as well as improvement in overall financial performance (Ladhari, 2009).

Further, there are several scales for measuring service quality. One of the most popular measure is SERVQUAL, whereas the scale is based on tangible and intangibles dimensions. Parasurman et al., (1985) introduced 10 determinants of service quality, however reduced the determinants to five, namely empathy, responsiveness, assurance, reliability, and tangibles (Parasurman et.al 1988).

Moreover, Nhat and Hau (2007) noted service quality has significant impact on customer satisfaction as well as customer perception, accordingly service quality is needed to create customer satisfaction. In line with this, Demir (2019a) defined satisfaction as a positive feeling toward the service received whereas satisfied customers are more likely to pay for that service again.

\subsection{Product Quality}

Product quality can be defined as an extent to which a product succeeds to meet the needs of customer (Lemmink \& Kasper, 1994). Moreover, product quality is one of the most important elements which satisfies customers and in turn provide competitive advantage (Flynn 1994; Aydinli \& Demir, 2015; Torlak et al., 2019).

Besides, Garvin (1988) has derived and identified eight dimensions as a basic of product quality that each dimension is self-contained and distinct; Performance: refers to the efficiency of a product to achieve its intended purpose. Features: the secondary 
characteristic of products which represents the extra supplement of performance. Reliability: the probability of product to failure. Conformance: the physical degree of a product to meet the pre-established standard. Durability: the extent of a product life. That the customers get benefit. Serviceability: refer to the speed, ease, courtesy, and competence of services. Aesthetics: the products look, feel, sound, and taste, the matter of personal preference. Perceived quality: the quality of a product based on image, brand name, and overall consumer feelings.

Further, Sebastianelli and Tamimmi (2002) have studied product quality in different ways, while the aim of the study was to find the relation between the product quality and quality definition approach both of which have been proposed by Garvin as well $(1984,1988)$. Accordingly, the classification is as followed;

1. Transcendent quality: "quality" is defined as innate excellence. The product or service will have unequalled properties and related to the durability of product (Pirsig, 1992).

2. Product based quality: is defined as the units of goodness packed into a product or service that the product is evaluated according to perceived quality, aesthetics, feature conformance, and performance (Garvin, 1984).

3. Manufacturing based quality: is defined as the conformance to the requirements, specification, and performance (Crosby, 1979).

4. User based (Customer based): "Quality" is defined as satisfying customer's requirements or fitness to purpose (Garvin, 1984).

Consequently, gated communities are considered as a constructed product and have become a trend of study by many researchers (Castledine \& Bannister, 1996; ConwayRahman 1997; Kam \& Tang, 1997; Low \& Omar, 1997; Low \& Yeo, 1998; Shammas Toma, 1998). According to Hilal and Top (2019) product quality had significant effect on repurchase intention, while product quality is more important to house holders compared to the service quality. However, Demir and Mukhlis (2017) state that gated communities in Kurdistan showed that the perceived quality of product has significant influence on repurchase intention. Likewise, Saadoon and Othman (2019) found that the serviceability and reliability is an important parameter for satisfying gated community residents. 
Furthermore, product quality is enhancing customer satisfaction and loyalty (Gallego, 2008; Bloemer, 1995). According to Pilkington and Chai (2008) higher quality of products lead to customer satisfaction and loyalty, which proves the positive relation between product quality and customer satisfaction (Jahanshahi et al., 2011). Likewise, Tsiotsou (2006) revealed that the perceived product quality resulted in customer satisfaction and repurchase intention.

\subsection{Satisfaction, Value, and Repurchase Intention}

Pleasure of a service or product after experience is called satisfaction (Kotler, 2000) whereas the customers intend to repurchase and suggest to others in case they are satisfied of a product or service (Kuo et al., 2018). Therefore, Kuo et al. (2018) suggested that satisfaction is a strong reason for the customers' revisit or purchase intention (Andaleeb and Conway 2006).

Besides, another positive intention driver is the value (Olaru et al., 2008). Value is considered as tradeoff between what customer receives as benefit comparing to what $\mathrm{s} / \mathrm{he}$ sacrifices to get it (Lin et al., 2005). Thus, when the benefits exceed costs, customer calls it valuable where it results in the repurchase for the product or service (Wathne et al., 2001). Consequently, this study is going to test the impact of product and service quality in gated communities on the satisfaction, value, and repurchase intention.

\section{Methodology}

\subsection{Model of the Study}

Based on the aforementioned literature, we have developed the following hypotheses.

H1 Product quality of houses in gated community affects customer satisfaction positively $\mathrm{H} 2$ Product quality of houses in gated community affects customer value perception positively

H3 Service quality of houses in gated community affects customer satisfaction positively H4 Service quality of houses in gated community affects customer value perception positively

H5 Customer satisfaction of houses in gated community affects customer value perception positively

H6 Customer value perceptions of houses in gated community affects customer repurchase intention positively 


\section{EJMSS Eurasian Journal of Management \& Social Sciences}

Hence, the model of the study is shown in Figure 2.

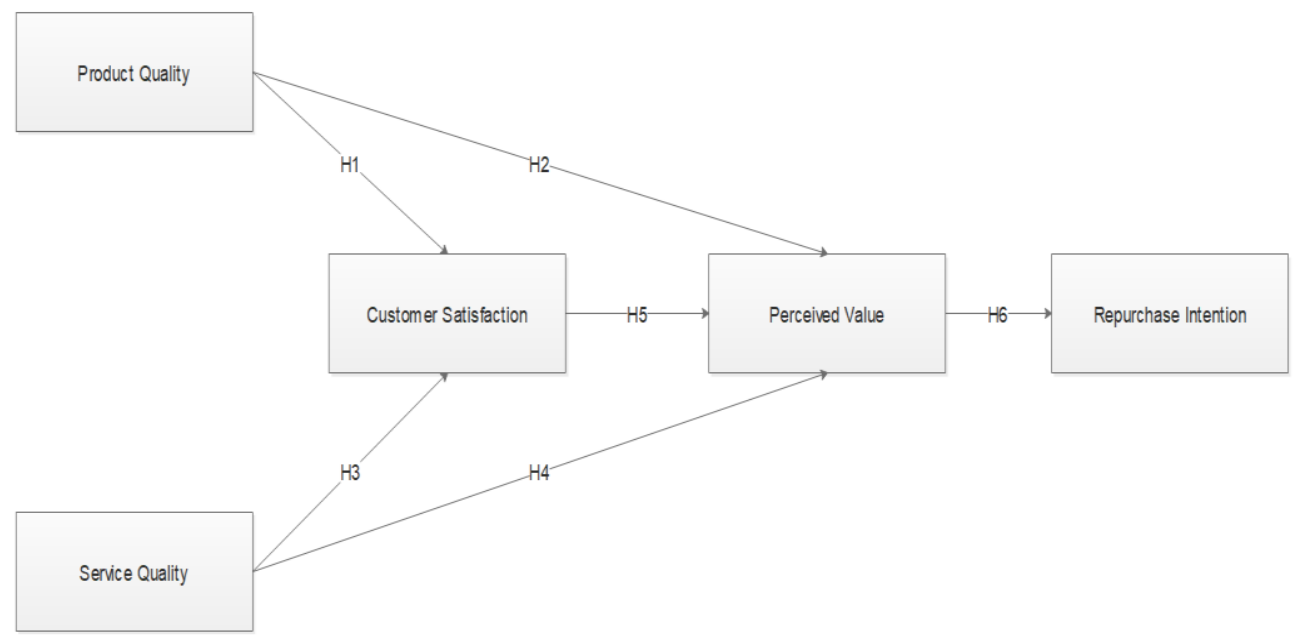

Figure 1: Research framework

\subsection{Sample}

The sample of this research was collected from various gated communities in Kurdistan Region of Iraq. Respondents were house owners or lessees of houses in those gated communities. Data was collected via survey questionnaire. Questions were asked to the residents face to face. In total, we have collected 320 responds from the residents.

\subsection{Instrumentation}

Survey questionnaire contained questions under product quality (nine items), service quality (seven items), Customer satisfaction (three items), perceived value (three items), and repurchase intention (three items). Product quality questions were adopted and modified from the study of Sebastianelli and Tamimi (2002), service quality questions were developed by the authors, customer satisfaction, repurchase intention and value questions were adopted and modified from Demir and Mukhlis (2017). 


\section{EJMSS Eurasian Journal of Management \& Social Sciences}

Likert scale was used to rate each item in the questionnaire whereas 1 represented strongly disagree and 7 represented strongly agree.

\section{Findings}

\subsection{Demographic Analysis}

Respondents predominantly were females (61\%) while only $39 \%$ of them were males. Among the respondents, there were equal number of lessees (55\%) as many as house owners (44\%). From each age group data were collected equally while only $3 \%$ were above 56 years old. Most of the respondents were living in a gated community up to three years (55\%) and between 3 and 5 years (32\%). Lastly, most of the houses were three bedrooms $(81 \%)$ only a few were more than with three bedrooms or less than three bedrooms.

Table 1: Demographic information of the respondents

\begin{tabular}{lcllllllll}
\hline Gender & $\%$ & Ownership & $\%$ & Age & $\%$ & $\begin{array}{l}\text { Living } \\
\text { there }\end{array}$ & $\%$ & $\begin{array}{l}\text { House } \\
\text { width }\end{array}$ & $\%$ \\
\hline Male & 39.1 & Owner & 44.1 & $\begin{array}{l}18- \\
25\end{array}$ & 23.8 & $\begin{array}{l}1-3 \\
\text { years }\end{array}$ & 55.2 & $\begin{array}{l}\text { one } \\
\text { bedroom }\end{array}$ & 1.0 \\
\hline Female & 60.9 & Rent & 55.2 & $26-$ & 32.5 & $3-5$ & 32.0 & two & 12.6 \\
& & & 35 & & years & & bedrooms & \\
\hline & & $36-$ & 27.7 & $5-7$ & 11.8 & three & 80.6 \\
& & 45 & & years & & bedrooms & \\
\hline & & $46-$ & 12.9 & $8+$ years & 1.0 & four \\
bedrooms & 5.5 \\
\hline & & 55 & & & & five & 0.3 \\
& & & $56+$ & 2.9 & & & bedrooms & \\
\hline
\end{tabular}

\subsection{Validation of the Questionnaire}

Exploratory factor analysis was employed to test the initial validity and Cronbach's Alpha for the initial reliability of the data set. Initially, Kaiser-Meyer-Olkin test result is important for the sufficiency of the data collected for this study. It must hold minimally 0.5 value. Secondly, Barlett's test of sphericity test result must be significant at $\mathrm{p}<0.05$. The results of the EFA in the current study shows that KMO was 0.86 and Barlett's test of sphericity was significant therefore, the collected data is sufficient to be evaluated further. 


\section{EJMSS Eurasian Journal of Management \& Social Sciences}

Table 2: Initial validity and reliability

\begin{tabular}{|c|c|c|c|c|c|}
\hline Questionnaire & Mean & S.D. & Communality & Loading & Alpha \\
\hline \multicolumn{6}{|l|}{ Product Quality } \\
\hline $\begin{array}{l}\text { Overall performance of pipelines } \\
\text { inside the gated community, } \\
\text { sewage system, internet, } \\
\text { telephone...etc., heat and sound } \\
\text { isolation, and air conditioners are } \\
\text { sufficient overall sufficient in this } \\
\text { gated community. }\end{array}$ & 3.64 & 0.94 & 0.51 & 0.59 & 0.769 \\
\hline $\begin{array}{l}\text { Features such as socialization } \\
\text { facilities, sport facilities, car } \\
\text { parking facilities, shopping } \\
\text { facilities, existence of preinstalled } \\
\text { features (kitchen, air conditioner, } \\
\text { bath...etc.), are sufficient }\end{array}$ & 3.54 & 0.94 & 0.56 & 0.64 & \\
\hline $\begin{array}{l}\text { Quality of the painting among the } \\
\text { apartments and houses, materials } \\
\text { used for each house and apartments } \\
\text { of the gated community, materials } \\
\text { executed inside the houses are all } \\
\text { standard (sufficient quality in every } \\
\text { house). }\end{array}$ & 3.85 & 0.94 & 0.54 & 0.54 & \\
\hline $\begin{array}{l}\text { Building quality, gardening, } \\
\text { roads...etc. fits the design conforms } \\
\text { my expectations }\end{array}$ & 3.55 & 0.95 & 0.57 & 0.68 & \\
\hline $\begin{array}{l}\text { The durability of the tiles, } \\
\text { paintings, materials used inside the } \\
\text { house and the gated community, }\end{array}$ & 3.46 & 0.91 & 0.58 & 0.69 & \\
\hline $\begin{array}{l}\text { There are sufficient warranty } \\
\text { conditions for houses and products } \\
\text { which are pre-installed }\end{array}$ & 3.66 & 1.00 & 0.51 & 0.65 & \\
\hline $\begin{array}{l}\text { How stylish, modern, exclusive the } \\
\text { plan, aesthetics the gardening, } \\
\text { aesthetics the materials and colors } \\
\text { chosen inside the gated community } \\
\text { and the houses. }\end{array}$ & 3.82 & 0.98 & 0.52 & 0.60 & \\
\hline $\begin{array}{l}\text { The materials (AC, Paint, } \\
\text { Concrete...etc.) used in these } \\
\text { houses are harmless for human, }\end{array}$ & 3.73 & 0.90 & 0.51 & 0.60 & \\
\hline
\end{tabular}




\section{EJMSS Eurasian Journal of Management \& Social Sciences}

harmless for nature, and energy

saver.

\begin{tabular}{|c|c|c|c|c|c|}
\hline $\begin{array}{l}\text { Image and name of this gated } \\
\text { community are very positive }\end{array}$ & 3.57 & 1.12 & 0.73 & 0.70 & \\
\hline \multicolumn{6}{|l|}{ Service Quality } \\
\hline Cleaning services are good & 3.54 & 1.15 & 0.74 & 0.79 & \multirow[t]{8}{*}{0.787} \\
\hline $\begin{array}{l}\text { Garbage collection services are } \\
\text { good }\end{array}$ & 3.64 & 0.96 & 0.58 & 0.69 & \\
\hline Water supply services are good & 3.90 & 1.02 & 0.67 & 0.75 & \\
\hline Electricity supply services are good & 3.85 & 1.01 & 0.55 & 0.65 & \\
\hline Security services are good & 3.60 & 1.03 & 0.59 & 0.65 & \\
\hline Gasoline supply services are good & 3.77 & 0.88 & 0.55 & 0.69 & \\
\hline $\begin{array}{l}\text { When there is a problem, } \\
\text { management handles and solves } \\
\text { problems }\end{array}$ & 3.76 & 0.97 & 0.63 & 0.62 & \\
\hline $\begin{array}{l}\text { Management communicates and } \\
\text { evaluates every household equally }\end{array}$ & 3.54 & 0.96 & 0.50 & 0.55 & \\
\hline \multicolumn{6}{|l|}{ Satisfaction } \\
\hline $\begin{array}{l}\text { This gated community highly } \\
\text { satisfaction to me }\end{array}$ & 3.47 & 0.96 & 0.52 & 0.50 & \multirow[t]{3}{*}{0.829} \\
\hline $\begin{array}{l}\text { I feel good experience of staying } \\
\text { here }\end{array}$ & 3.28 & 1.01 & 0.55 & 0.57 & \\
\hline I like living here for long time & 3.36 & 0.99 & 0.53 & 0.64 & \\
\hline \multicolumn{6}{|l|}{ Value } \\
\hline $\begin{array}{l}\text { I feel I got money's worth at this } \\
\text { gated community }\end{array}$ & 3.19 & 1.00 & 0.53 & 0.65 & \multirow[t]{3}{*}{0.868} \\
\hline $\begin{array}{l}\text { This gated community offers good } \\
\text { value for the money }\end{array}$ & 3.31 & 0.92 & 0.59 & 0.65 & \\
\hline $\begin{array}{l}\text { The value this gated community } \\
\text { deserves its price }\end{array}$ & 2.26 & 0.66 & 0.52 & 0.61 & \\
\hline \multicolumn{6}{|l|}{ Repurchase Intention } \\
\hline $\begin{array}{l}\text { If I have opportunity, I will buy/rent } \\
\text { from the same gated community }\end{array}$ & 2.81 & 1.20 & 0.54 & 0.69 & \multirow[t]{2}{*}{0.725} \\
\hline $\begin{array}{l}\text { I advise this gated community to } \\
\text { my acquaintances }\end{array}$ & 3.68 & 0.86 & 0.51 & 0.63 & \\
\hline
\end{tabular}


Eurasian Journal of Management \& Social Sciences

If I sell/leave renting this house, I will buy/rent a house from the same gated community

For any survey questionnaire, it is required that extracted variance for it overall must be above $50 \%$. Secondly, Eigen values for each group of questionnaires must hold 1 in order to call that group of question as dimension. In this study, extracted variance of questionnaire was $61 \%$ at five construct that hold sufficient Eigen value each. Table 2 shows the details about items under each construct. Initial reliability of the questionnaire was checked by Cronbach's Alpha level. For each construct, Cronbach's Alpha must hold minimum 0.7 value to be considered as reliable. Given in the Table 2, each dimension held alpha level above 0.7 thus, initial reliability of the questionnaire was achieved.

After the factor analysis, discriminant and convergent validity must be checked in order to validate the questionnaire. Convergent validity shows how reliably each construct was grouped and is measured by two determinants; composite reliability and average variance extracted. However, discriminant validity is measured by the distance between square root of average variance extracted by a latent variable and the correlation of that latent variable with the other constructs. In this manner, square root of average variance extracted must be above the correlation values.

Table 3: Discriminant and convergent validity

\begin{tabular}{llllllll}
\hline & CR & AVE & 1 & 2 & 3 & 4 & 5 \\
\hline Service Quality & 0.812 & 0.518 & $0.647^{\mathrm{a}}$ & & & & \\
\hline Customer Satisfaction & 0.733 & 0.563 & $0.583^{\mathrm{b}}$ & 0.681 & & & \\
\hline Perceived Value & 0.710 & 0.539 & 0.515 & 0.617 & 0.662 & & \\
\hline Repurchase Intention & 0.766 & 0.621 & 0.354 & 0.398 & 0.606 & 0.788 & \\
\hline Product Quality & 0.790 & 0.536 & 0.568 & 0.558 & 0.620 & 0.386 & 0.622 \\
\hline
\end{tabular}

Given in Table 3, composite reliability of each construct is above 0.7 and average variance extracted for each latent variable is above 0.5 . Therefore, convergent validity was achieved. Secondly, square root of average variance extracted is above the correlation of that construct comparing to other dimensions. Hence, discriminant validity is achieved. 


\section{EJMSS}

\section{Eurasian Journal of Management \& Social Sciences}

\subsection{Testing Hypotheses}

We have used structural equations modeling to test the hypotheses of the research. To do this, we have used IBM AMOS software. Model fit values play an important role in accepting the results of the model as accurate. There are mainly two model fit variables as: comparative fit values and absolute fit values. In this study, we have used comparative fit index (CFI) for the comparative fit value determination and $\mathrm{x}^{2} / \mathrm{df}$, RMSEA, GFI, and AGFI for the absolute fit values. Given in Table 4, CFI value was $0.92, \mathrm{x}^{2} / \mathrm{df}$ was 2.281 , RMSEA was 0.057 , GFI was 0.87 and AGFI was 0.85 . Thus, both comparative fit values and absolute fit values were sufficient to measure the aforementioned model of the study.

It was indicated that service and product quality in the gated communities explained 58\% of the overall variance on customer satisfaction. Further, service quality, product quality, and customer satisfaction explained $76 \%$ of the variance on the perceived value. Lastly, service quality, product quality, customer satisfaction, and perceived value explained $65 \%$ of the variance on repurchase intention.

Table 4: Results of the hypotheses

\begin{tabular}{|c|c|c|c|c|c|c|c|}
\hline $\begin{array}{l}\text { Dependent } \\
\text { Variable }\end{array}$ & & $\begin{array}{l}\text { Independent } \\
\text { Variable }\end{array}$ & Estimate & S.E. & C.R. & $\mathrm{P}$ & Result \\
\hline $\begin{array}{l}\text { Customer } \\
\text { Satisfaction }\end{array}$ & $<--$ & Service Quality & 0.225 & .104 & 2.161 & .031 & Accepted \\
\hline $\begin{array}{l}\text { Perceived } \\
\text { Value }\end{array}$ & $<---$ & Service Quality & 0.028 & .095 & 0.292 & .770 & Rejected \\
\hline $\begin{array}{l}\text { Customer } \\
\text { Satisfaction }\end{array}$ & $<---$ & Product Quality & 0.623 & .159 & 3.926 & $* * *$ & Accepted \\
\hline $\begin{array}{l}\text { Perceived } \\
\text { Value }\end{array}$ & $<---$ & Product Quality & 0.490 & .164 & 2.982 & .003 & Accepted \\
\hline $\begin{array}{l}\text { Perceived } \\
\text { Value }\end{array}$ & $<---$ & $\begin{array}{l}\text { Customer } \\
\text { Satisfaction }\end{array}$ & 0.543 & .131 & 4.157 & $* * *$ & Accepted \\
\hline $\begin{array}{l}\text { Repurchase } \\
\text { Intention }\end{array}$ & $<---$ & $\begin{array}{l}\text { Perceived } \\
\text { Value }\end{array}$ & 0.790 & 0.12 & 6.650 & $* * *$ & Accepted \\
\hline $\mathrm{X}^{2} / \mathrm{df}=$ & 2.281 & & \multirow{5}{*}{\multicolumn{5}{|c|}{$\begin{array}{l}\mathrm{SMC}_{\text {customer satisfaction }}=58 \% \\
\mathrm{SMC}_{\text {perceived value }}=76 \% \\
\mathrm{SMC}_{\text {repurchase intention }}=65 \%\end{array}$}} \\
\hline $\mathrm{CFI}=$ & 0.92 & & & & & & \\
\hline $\mathrm{GFI}=$ & 0.87 & & & & & & \\
\hline $\mathrm{AGFI}=$ & 0.85 & & & & & & \\
\hline RMSEA= & 0.057 & & & & & & \\
\hline
\end{tabular}




\section{EJMSS Eurasian Journal of Management \& Social Sciences}

The results of the model show that product quality in the gated communities affect the customer satisfaction $(\beta=0.623, \mathrm{t}=3.926, \mathrm{p}<0.01)$ and perceived value $(\beta=0.490, \mathrm{t}=2.982$, $\mathrm{p}<0.01)$ positively and significantly. Hence, $\mathrm{H} 1$ and $\mathrm{H} 2$ were accepted. Moreover, service quality in the gated communities influenced customer satisfaction $(\beta=0.225, \mathrm{t}=2.161$, $\mathrm{p}<0.05)$ positively and significantly while it didn't have any significant impact on the perceived value $(\beta=0.028, \mathrm{t}=0.292, \mathrm{p}>0.05)$ of the residents in gated communities. Therefore, $\mathrm{H} 3$ was accepted and $\mathrm{H} 4$ was rejected.

Given in Table 4, customer satisfaction was a strong influencer on the perceived value ( $\beta=$ 0.543, $\mathrm{t}=4.157, \mathrm{p}<0.01)$ and repurchase intention $(\beta=0.790, \mathrm{t}=6.650, \mathrm{p}<0.01)$. Thus, H5 and H6 was accepted. For the further details, see Table 4 and Figure 2.

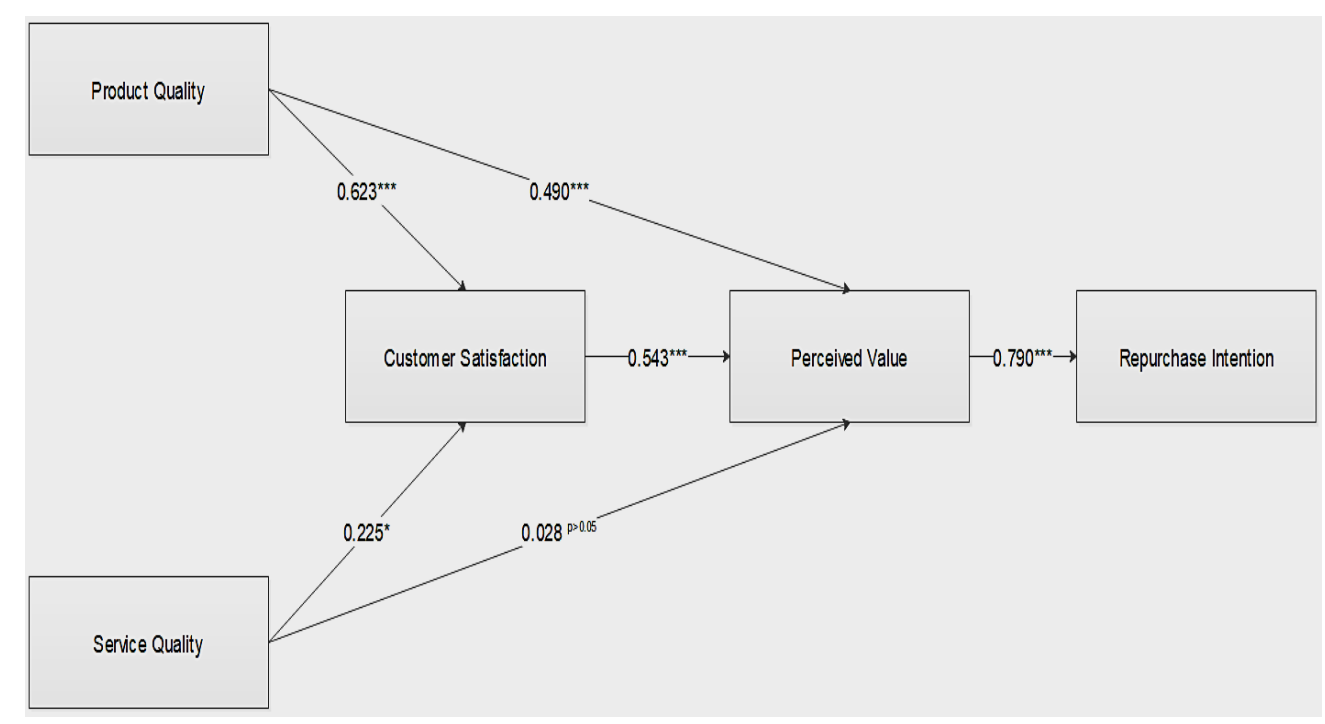

Figure 2: Results of the hypothesized model

\section{Conclusion}

Repurchase intention is one of the most important determinants of business success in gated communities. Investors continue selling real estates to the purchasers in case the previous experiences of them are positive. From this point of view, the current study aimed to elaborate the antecedents of repurchase intention in gated communities. To do this, we have collected data via questionnaire from various residents of the gated communities in 
Kurdistan Region of Iraq. Secondly, we have tested the impact of product quality, service quality, customer satisfaction, and perceived value on the repurchase intention in the gated communities. The results of the analyses showed that repurchase intention among the residents are below the average. Therefore, it is suggested to management of the gated communities to develop a strong strategy to increase the repurchase intentions of the residents.

It was observed that perceived value was the strongest influencer of the repurchase intention in the gated community. Secondly, customer satisfaction was an important determinant on the perceived value. Satisfaction of the residents were tested over the service and product quality. It was observed that product quality was stronger influencer on the customer satisfaction rather than service quality. Besides, importance of service quality on the customer satisfaction was undeniable due to the significant impact on it. Therefore, managers in the gated communities are suggested to increase the product quality of the houses in the gated communities and develop strategies in the gated communities to increase the services to the residents.

Day by day number of gated communities are increasing in Kurdistan Region of Iraq. Hence, competitiveness among the investors also increase. From this point of view, new strategies should be developed to keep the residents loyal to that gated community. Hence, service quality in the gated community plays more important role than it has been ever. From this point of view, managers should care about the services they provide for their residents.

There are limitations of the current study. We have collected data from the residents in Kurdistan Region of Iraq. It can't be generalized to all Iraq and Middle East. Hence, further studies should be conducted in all Iraq and various countries in all over the Middle East. Secondly, the study didn't test the impact of switching cost of a house in a gated community which prevents a resident to move to another gated community. Thus, future studies may take switching cost in gated communities into account to test the impact on the repurchase intentions. 


\section{EJMSS}

\section{Eurasian Journal of Management \& Social Sciences}

\section{References}

Conway- Rahman, H. (1997). Some observations on the issues of quality cost in construction. International Journal of Quality \& Reliability Management, 14 (5), 464-481.

Ali, S. H., \& Yildiz, Y. (2020). Leadership effects on CSR employee, media, customer, and NGOs. Manag. Econ. Res. J, 6(2020), 12354.

Ali, S. H. K., Khan, N. S., \& Yildiz, Y. (2020). Leadership effects on CSR employee, media, customer, and NGOs. Management and Eco-nomics Research Journal, $6,1-9$.

Atkinson, R., Blandy, S., Flint, J., \& Lister, D. (2005). Gated cities of today? Barricaded residential development in England. Town Planning Review, 76(4), 401-422.

Aydinli, C., \& Demir, A. (2015). Impact of non-technical dimensions of service quality on the satisfaction, loyalty, and the willingness to pay more: a cross-national research on GSM operators. International Journal of Economics, Commerce and Management, 3(11), 1-16.

Bolemer, J. M. M., \& Lemmink, J. G. A. M. (1995). The importance of customer satisfaction in explaining brand and dealer loyalty [J]. Journal of Marketing Management, 8(4), 351-363.

Bowen, J., \& Ford, R. C. (2002). Managing service organizations: Does having a "thing" make a difference? Journal of Management, 28(3), 447-469.

Budur, T. (2018a). Analytic Hierarchy Process to Evaluate Corporate Image, Trust, and Switching Cost of GSM Operators: A Case of Kurdistan Region of Iraq. International Journal of Social Sciences \& Educational Studies, 5(2), 241-250

Budur, T. (2018b). The impact of Al-Ghazali's virtues on organizational commitment and performance: A case Study at private education institutions in Kurdistan Region of Iraq. Icabep, Erbil-Iraq, 2, p21.

Budur, T., Faraj, K. M., \& Karim, L. A. (2019). Benchmarking operations strategies via hybrid model: A case study of café-restaurant sector. Amazon Investiga, 8 , 842-854.

Budur, T., \& Demir, A. (2019a). Leadership effects on employee perception about CSR in Kurdistan Region of Iraq. International Journal of Social Sciences \& Educational Studies, 6(1). 142-154.

Budur, T., \& Demir, A. (2019b). Leadership perceptions based on gender, experience, and education. International Journal of Social Sciences \& Educational Studies, 6(1), 142-154.

Budur, T., Rashid, C. A., \& Poturak, M. (2018). Students' perceptions on university selection, decision making process: A case study in Kurdistan Region of Iraq. International Journal of Social Sciences \& Educational Studies, 5(1), 133-144. 
Castledine, D., \& Bannister, B. (1996). The role of ISO 9000 in improving the quality of service delivery of Hong Kong's public housing programs. International Journal of Public Administration, 19(11-12), 2167-2193.

Cronin Jr, J. J., Brady, M. K., \& Hult, G. T. M. (2000). Assessing the effects of quality, value, and customer satisfaction on consumer behavioral intentions in service environments. Journal of Retailing, 76(2), 193-218.

Crosby, P. B. (1979). Quality is free: The art of making quality cer-tain (Vol. 94). New York: McGraw-hill.

Demir, A. (2019a). A Benchmarking of service quality in telecommunication services: Case study in Kurdistan Region of Iraq. International Journal of Social Sciences \& Educational Studies, 5(3), 216-231.

Demir, A. (2019b). The impact of strategic operations management decision on shoppers' wellbeing. Asian Academy of Management Journal, 24(1), 25-57.

Demir, A., \& Aydinli, C. (2016). Exploring the quality dimensions of mobile instant messaging applications and effects of them on customer satisfaction. International Journal of Computer Theory and Applications, 9(22), 1-15.

Demir, A., \& Budur, T. (2019). Roles of leadership styles in corporate social responsibility to non-governmental organizations (NGOs). International Journal of Social Sciences \& Educational Studies, 5(4), 174-183.

Demir A, Shawkat S, Majeed BN, Budur T. (2019). Fuzzy AHP and VIKOR to select best location for bank investment: case study in Kurdistan Region of Iraq. In Effective Investments on Capital Markets, Tarczyn'sk W, Nermend K (eds). Springer: Cham; 485-510.

Demir, A., \& Guven, S. (2017). The influence of ISO certificate on quality evaluation of students: a case study at Ishik University. Advances in Social Sciences Research Journal, 4(3)171-180.

Demir, A., \& Mukhlis, M. (2017). An evaluation of gated communities as a product: An empirical study in Sulaimaniyah, Iraq. Theoretical and Empirical Researches in Urban Management, 12(3), 63-84.

Demir, A., Özmen, Ö., \& Rashid, A. (2014). An Estimation of Turkey's Export Loss to Iraq. Procedia-Social and Behavioral Sciences, 150(2014), 1240-1247.

Flynn, B. B. (1994). The relationship between quality management practices, infrastructure and fast product innovation. Benchmarking for Quality Management \& Technology, 1(1), 48-64.

Garvin, D. A. (1988). Managing quality: The strategic and competitive edge. Simon and Schuster.

Garvin, D. A. (1984). What does "Product Quality" really mean? Sloan Management Review (pre-1986), 26(1), 25-43. 
Greenberg, S. W. Rohe, W. (1984). Neighborhood design and crime. Journal of the American Planning Association, 50 (1), 48-61.

Hilal, D., \& Top, C. (2019). Impact of product and service quality of gated communities on the repurchase intentions: A case study in Kurdistan Region of Iraq. International Journal of Economics, Commerce and Management, 7(6)505515.

Hokanson, S. (1995). The deeper you analyze, the more you satisfy customers. Marketing News, 29(1).

Khan, N. U. S., \& Yildiz, Y. (2020). Impact of Intangible Characteristics of Universities on Student Satisfaction. Amazonia Investiga, 9(26), 105-116.

Jaf, K., Muhammed, P., \& Omer, A. (2019). Provider-Customer perceptions in service quality: A gap analysis at Ishik University, Sulaimani, Iraq. Manag. Econ. Res. $J, 5(2019), 13$.

Jahanshahi, A. A., Gashti, M. A. H., Mirdamadi, S. A., Nawaser, K., \& Khaksar, S. M. S. (2011). Study the effects of customer service and product quality on customer satisfaction and loyalty. International Journal of Humanities and Social Science, 1(7), 253-260.

Kam, C. W., \& Tang, S. L. (1997). Development and implementation of quality assurance in public construction works in Singapore and Hong Kong. International Journal of Quality \& Reliability Management, 14 (9), 909928.

Kotler, P. (2000). Marketing Management. 10th ed., New Jersey, Prentice-Hall.

Kovács, Z., \& Hegedüs, G. (2014). Gated communities as new forms of segregation in post-socialist Budapest. Cities, 36(2014), 200-209.

Kuo, T., Chen, C.T., \& Cheng, W.J. (2018). Service quality evaluation: moderating influences of first-time and revisiting customers. Total Quality Management \& Business Excellence, 29(3-4), 429-440.

Ladhari, R. (2009). Service quality, emotional satisfaction, and behavioral intentions: A study in the hotel industry. Managing Service Quality, 19(3), 308-331.

Lai, L. W. (2016). Stone walls do not a prison make, nor iron bars a cage: The institutional and communitarian possibilities of gated communities. Land Use Policy, 54(2016), 378-385.

Lemmink, J., \& Kasper, H. (1994). Competitive reactions to product quality improvements in industrial markets. European Journal of Marketing, 28 (12), 50-68.

Lin, C., Sher, P., \& Shih, H. (2005). Past progress and future direction in conceptualizing customer perceived value", International Journal of Service Industry Management, 16(4), 318-36. 
Low, S. P., \& Omar, H. F. (1997). The effective maintenance of quality management systems in the construction industry. International Journal of Quality \& Reliability Management, 14(8), 768-790.

Low, S. P., \& Yeo, H. K. (1998). A construction quality costs quantifying system for the building industry. International Journal of Quality \& Reliability Management, 15(3), 329-349.

Mohammed, S. S., Suleyman, C., \& Taylan, B. (2020). Burnout Determinants and Consequences Among University Lecturers. Amazonia Investiga, 9(27), 13-24.

Nhat, N. D. D., \& Hau, L. N. (2007). Determinants of retail service quality-a study of supermarkets in Vietnam. Science \& Technology Development, 10(8), 15-23.

Olaru, D., Purchase, S., \& Peterson, N. (2008). From customer value to repurchase intentions and recommendations. Journal of Business \& Industrial Marketing, $23(8), 554-565$.

Özmen, Ö., Demir, A., \& Celepli, M. (2013). An Analysis of Iraq's Pre-import Inspection, Testing \& Certification Program: A’WOT Analysis. ProcediaSocial and Behavioral Sciences, 99(13), 85-93.

Parasuraman, A., Zeithaml, V.A., \& Berry, L.L. (1988). Servqual: a multiple-item scale for measuring consumer perceptions of service quality. Journal of Retailing, 64(1), 12.

Parasuraman, A. (1998). Customer service in business- to- business markets: an agenda for research. Journal of Business \& Industrial Marketing, 13(4/5), 309-321.

Parasuraman, A., Zeithaml, V., \& Berry, L.L. (1985). A conceptual model of service quality and its implications for future research. Journal of Marketing. 49 (4), $41-51$.

Parikh, D. (2006). Measuring retail service quality: an empirical assessment of the instrument. Vikalpa, 31(2), 45-56.

Pilkington, A., \& Chai, K. H. (2008). Research themes, concepts and relationships. International Journal of Service Industry Management, 19(1), 83-110.

Porter, M. E. (1985). Competitive advantage free press. New York. 33-61.

Sebastianelli, R., \& Tamimi, N. (2002). How product quality dimensions relate to defining quality. International Journal of Quality \& Reliability Management, 19(4), 442-453.

Serin, H. (2018). The use of extrinsic and intrinsic motivations to enhance student achievement in educational settings. International Journal of Social Sciences \& Educational Studies, 5(1), 191-194.

Shahin, A., \& Samea, M. (2010). Developing the models of service quality gaps: A critical discussion. Business Management and Strategy, 1(1), 2. 


\section{EJMSS Eurasian Journal of Management \& Social Sciences}

Shammas-Toma, M., Seymour, D., \& Clark, L. (1998). Obstacles to implementing total quality management in the UK construction industry. Construction Management \& Economics, 16(2), 177-192.

Smigiel, C. (2014). Reprint of "The production of segregated urban landscapes: A critical analysis of gated communities in Sofia". Cities, 36(2014), 182-192.

Torlak, N. G., Demir, A., \& Budur, T. (2019). Impact of operations management strategies on customer satisfaction and behavioral intentions at caférestaurants. International Journal of Productivity and Performance Management, 1(1).

Tsiotsou, R. (2006). The role of perceived product quality and overall satisfaction on purchase intentions. International Journal of Consumer Studies, 30(2), 207217.

Wathne, K., Biong, H., \& Heide, J. (2001). Choice of supplier in embedded markets: relationship and marketing program effects. Journal of Marketing, 65 (2), 54 66.

Wright, S. (1921). Correlation and causality. Journal of Agricultural Research, 20, 557585.

Wright, S. (1934). The method of path coefficients. Annals of Mathematical Statistics, $5(3), 161-215$

Yildiz, Y., \& Budur, T. (2019). Introducing Environmental Awareness to College Students with Curricular and Extracurricular Activities. International Journal of Academic Research in Business and Social Sciences, 9(3), 667-675.

Zhang, Q., Vonderembse, M. A., \& Lim, J. S. (2003). Manufacturing flexibility: Defining and analyzing relationships among competence, capability, and customer satisfaction. Journal of Operations Management, 21(2), 173-191. 